\title{
The use of remote sensing to quantify wetland loss in the Choke Mountain range, Upper Blue Nile basin, Ethiopia
}

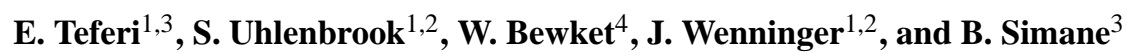 \\ ${ }^{1}$ UNESCO-IHE Institute for Water Education, P.O. Box 3015, 2601 DA Delft, The Netherlands \\ ${ }^{2}$ Delft University of Technology, Department of Water Management, P.O. Box 5048, 2600 GA Delft, The Netherlands \\ ${ }^{3}$ Institute for Environment, Water and Development Studies, Addis Ababa University, P.O. Box 2176, Addis Ababa, Ethiopia \\ ${ }^{4}$ Department of Geography and Environmental Studies, Addis Ababa University, P.O. Box 2176, Addis Ababa, Ethiopia
}

Received: 1 July 2010 - Published in Hydrol. Earth Syst. Sci. Discuss.: 25 August 2010

Revised: 17 November 2010 - Accepted: 22 November 2010 - Published: 3 December 2010

\begin{abstract}
Wetlands provide multiple ecosystem services such as storing and regulating water flows and water quality, providing unique habitats to flora and fauna, and regulating micro-climatic conditions. Conversion of wetlands for agricultural use is a widespread practice in Ethiopia, particularly in the southwestern part where wetlands cover large areas. Although there are many studies on land cover and land use changes in this region, comprehensive studies on wetlands are still missing. Hence, extent and rate of wetland loss at regional scales is unknown. The objective of this paper is to quantify wetland dynamics and estimate wetland loss in the Choke Mountain range (area covering $17443 \mathrm{~km}^{2}$ ) in the Upper Blue Nile basin, a key headwater region of the river Nile. Therefore, satellite remote sensing imagery of the period 1986-2005 were considered. To create images of surface reflectance that are radiometrically consistent, a combination of cross-calibration and atmospheric correction (Vogelman-DOS3) methods was used. A hybrid supervised/unsupervised classification approach was used to classify the images. Overall accuracies of $94.1 \%$ and $93.5 \%$ and Kappa Coefficients of 0.908 and 0.913 for the 1986 and 2005 imageries, respectively were obtained. The results showed that $607 \mathrm{~km}^{2}$ of seasonal wetland with low moisture and $22.4 \mathrm{~km}^{2}$ of open water are lost in the study area during the period 1986 to 2005 . The current situation in the wetlands of Choke Mountain is characterized by further degradation which calls for wetland conservation and rehabilitation efforts through incorporating wetlands into watershed management plans.
\end{abstract}

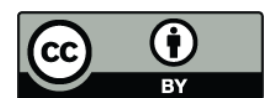

Correspondence to: E. Teferi (ermias52003@yahoo.com)

\section{Introduction}

It is well documented that wetlands play critical roles in the hydrological system (e.g. Ehrenfeld, 2000; Tiner, 2003). Moderating the impact of extreme rainfall events and providing base flow during dry periods is one of the key functions of wetlands. On the one hand, wetlands can moderate flow dynamics and mitigate flooding. On the other hand, they play a regulating role on the water quality by capturing sediment and capturing and converting pollutants. Wetland functions are particularly important in areas with high rainfall variability as they help to sustain smaller discharges during the dry season and, consequently, improve the availability of water. Therefore, wetland conservation has a vital role to play in alleviating water problems at different scales (e.g. Koeln, 1992; Jensen et al., 1993; Reimold, 1994).

Estimates of global wetland area range from 5.3 to 12.8 million $\mathrm{km}^{2}$ (Mathews and Fung, 1987; Finlayson et al., 1999). About half the global wetland area has been lost as a result of human activities (OECD, 1996). In tropical and subtropical areas conversions of wetlands to alternative land uses have accelerated wetland loss since the 1950s (Moser et al., 1996) and agriculture is considered the principal cause for wetland loss. The degradation and loss of headwater wetlands leads to increased flooding, soil erosion, degradation of water quality, reduced dry season flows, lower groundwater tables and less availability of water and moisture during the dry season. In Ethiopia due to limited research work on wetland resources, the management of wetlands is impaired by the general public and decision makers. Hence many of the wetlands are drying up and disappearing; a good example is the collapse of Lake Alemaya in Eastern Ethiopia (Lemma, 2004; Yohannes, 2005).

Published by Copernicus Publications on behalf of the European Geosciences Union. 
In the Blue Nile basin, wetlands in general are given limited attention and the role of headwater wetlands is especially not well addressed. This seems to be somewhat different for the White Nile basin, where the ecosystem functioning and its services were studied in the Lake Victoria region (Loiselle et al., 2006; Van Dam et al., 2007) and the Sudd wetland in Sudan (Mohamed et al., 2005). It is common that small headwater wetlands are ignored in wetland studies and often the importance of large wetlands is recognized and appreciated. But these seemingly insignificant individual wetlands can collectively play important roles in moderating flows and improving water quality (McKergow et al., 2007). A large number of such small wetlands, ranging from sedge swamps to seasonally flooded grasslands, exist in the Mt. Choke headwater areas. However, very little is known about the spatial distribution, the variability in space and time and their hydrological and ecological functioning. Most previous research on wetland was conducted in southwest Ethiopia with a focus on wetland management and policy implications (Hailu et al., 2003; Wood, 2000), hydrological impacts of wetland cultivation (Dixon, 2002; Dixon and Wood, 2003), socio-economic determinants (Mulugeta, 1999), and gender dimension of wetland use (Wood, 2001).

An effective and efficient management of wetlands requires an exhaustive survey (mapping) of their distribution and determination of whether or not they have changed over time and to what extent (Jensen et al., 1993; Baker et al., 2006). Ground-based survey of wetlands of large, or even small, wetlands is very time consuming. The use of remote sensing techniques offers a cost effective and time saving alternative for delineating wetlands over a large area compared to conventional field mapping methods (Ozesmi and Bauer, 2002; Töyrä and Pietroniro, 2005). Landsat, Satellite Pour l'Observation de la Terre (SPOT), Advanced Very High Resolution Radiometer (AVHRR), Indian Remote Sensing satellites (IRS), radar systems (Ozesmi and Bauer, 2002), Advanced Space-borne Thermal Emission and Reflection Radiometer (ASTER) (Wei et al., 2008; Pantaleoni et al., 2009) and Moderate-resolution Imaging Spectroradiometer (MODIS) (Callan and Mark, 2008) are the most frequently used satellite sensors for wetland detection. However, there is no standard method for computer-based wetland classification (Frazier and Page, 2000).

The aim of this study is to quantify wetland dynamics and estimate wetland loss in the Choke Mountain range. To achieve this objective, a hybrid supervised/unsupervised classification of Landsat imagery acquired in 1986 and 2005 were considered. Before classification it was necessary to create images of surface reflectance that are radiometrically consistent and to ensure interimage comparability between TM and ETM+ images. This was done by applying a combination of cross-calibration and atmospheric correction (Vogelman-DOS3) methods (Paolini et al., 2006). Following this introduction, the definition of wetlands implemented in this paper is given. The remainder of this paper is sub- divided into three sections. The materials and methods are described in the first section, following which there is a section on Result and Discussion. The paper ends with a section on Conclusion.

\section{Definition of wetlands}

Successful identification of wetlands starts with a clear definition of wetlands. Numerous wetland definitions have been developed for various purposes. Most recent ones are definition given by RAMSAR and USGS. The Ramsar convention (Ramsar Convention Secretariat, 2006) defined wetlands as: “.... areas of marsh, fen, peatland or water, whether natural or artificial, permanent or temporary, with water that is static or flowing, fresh, brackish or salt, including areas of marine water the depth of which at low tide does not exceed six metres." The United States Geological Survey (USGS) defined wetland as a general term applied to land areas which are seasonally or permanently waterlogged, including lakes, rivers, estuaries, and freshwater marshes; an area of lowlying land submerged or inundated periodically by fresh or saline water (Mac et al., 1998). Taking the RAMSAR and USGS definitions into consideration, the wetlands mapped in this study included water bodies (static or flowing water), seasonal wetlands with high moisture, and seasonal wetlands with low moisture. Riparian vegetations were not included in the wetland classes of this study.

\section{Materials and methods}

\subsection{The study area}

The study area covers the whole of the Choke Mountain range, the most important source of water for the Blue Nile river system in Ethiopia. The area extends between $10^{\circ}$ to $11^{\circ} \mathrm{N}$ and $37^{\circ} 30^{\prime}$ to $38^{\circ} 30^{\prime} \mathrm{E}$, the highest peak is located at $10^{\circ} 42^{\prime} \mathrm{N}$ and $37^{\circ} 50^{\prime} \mathrm{E}$. It is situated in the south of Lake Tana, in the central part of the Amhara National State of Ethiopia (Fig. 1). Elevation extends from $810 \mathrm{~m}$ a.s.l. to $4050 \mathrm{~m}$ a.s.l. The mean annual rainfall varies between $995 \mathrm{~mm} \mathrm{a}^{-1}$ and $1864 \mathrm{~mm} \mathrm{a}^{-1}$ based on data from 13 stations for the years 1971-2006. The mean annual temperature ranges from $7.5^{\circ} \mathrm{C}$ to $28^{\circ} \mathrm{C}$ (BCEOM, 1998a).

The Choke Mountain is the water tower of the region serving as headwater of the upper Blue Nile basin. Many of the tributaries of the Upper Blue Nile originate from this mountain range. A total of 59 rivers, and many springs are identified in the upper catchments of Choke Mountain. The Blue Nile is the largest tributary of the Nile river, the runoff being generated almost all in Ethiopia. Estimates of the mean annual flow range from $45.9 \times 10^{9} \mathrm{~m}^{3} \mathrm{a}^{-1}$ to $54 \times 10^{9} \mathrm{~m}^{3} \mathrm{a}^{-1}$ (UNESCO, 2004; Conway, 2005). The annual sediment discharge of the basin at the Sudanese border is between $130 \times 10^{6} \mathrm{ta}^{-1}$ and $335 \times 10^{6} \mathrm{ta}^{-1}$ (BCEOM, 


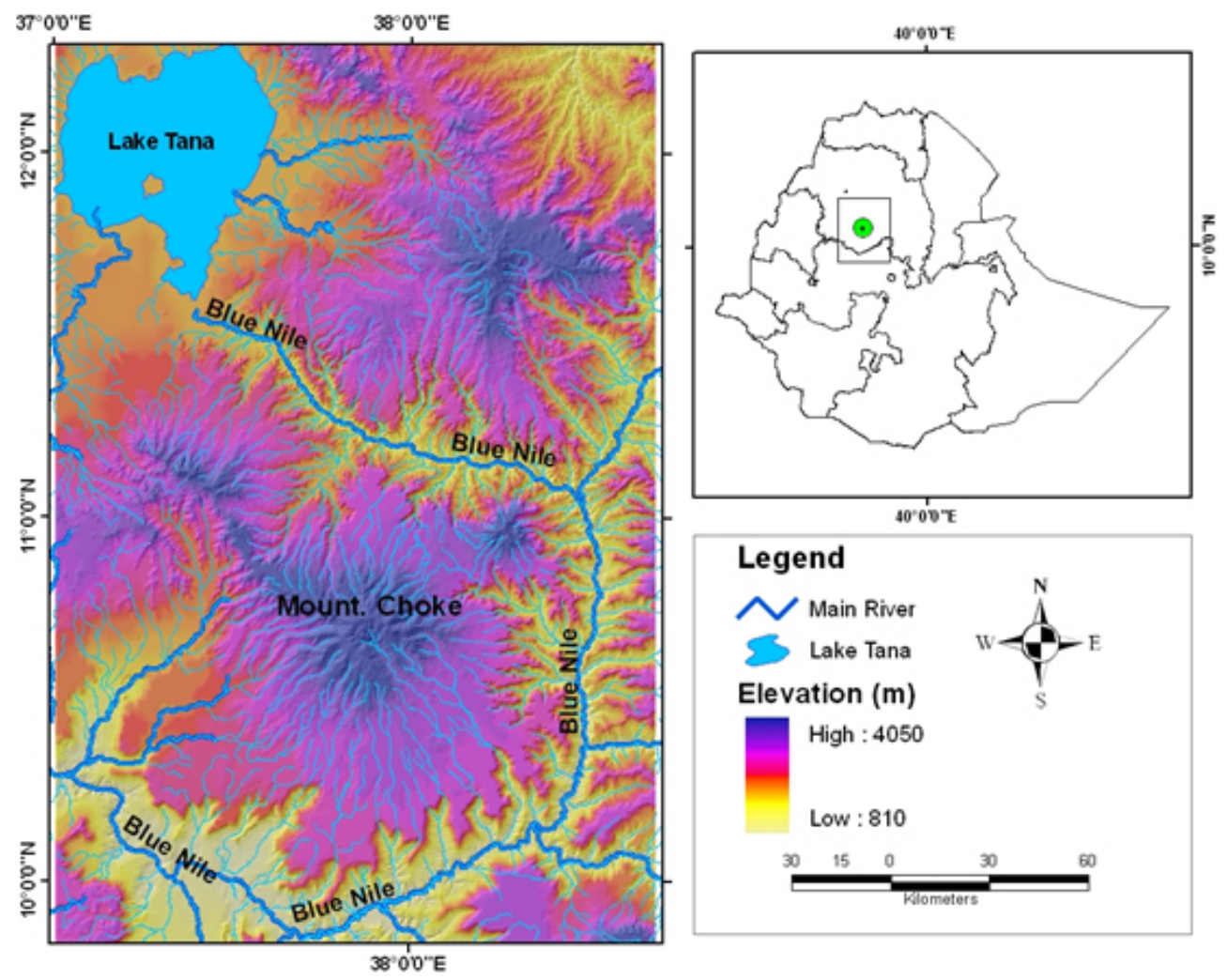

Fig. 1. The location and topography of the study area.

1998b). The major sources of sediment is erosion of the intensively farmed highland areas in the central and eastern parts of the basin (Bewket and Teferi, 2009; UNESCO, 2004; Zeleke, 2000).

The main geological unit in the area is the Tarmaber Gussa formation which represents Oligocene to Miocene basaltic shield volcanoes with minor trachyte and phonolite intrusions (Tefera et al., 1999). The soil units covering the Choke Mountain are Haplic Alisols (deep soils with predominant clay or silt-clay texture), Eutric Leptosols (shallow soils with loam or clay-loam texture) and Eutric Vertisols (deep soils with clayey texture and angular/sub-angular blocky structure) (BCEOM, 1998c). Due to active morphological processes (erosion, land slides etc.) the soil depth can vary between zero and several meters.

There is no longer significant natural forest cover in this mountain range. The major remaining natural habitats are moisture moorland, sparsely covered with giant lobelias ( $\mathrm{LO}$ belia spp.; Jibara/Jibbra), lady's mantle (Alchemilla spp.), Guassa grass (Festuca spp.) and other grasses. There is very little natural woody plant cover; heather (Erica spp.; Asta) and Hypericum (Hypericum revolutum; Amijja) are found in patches. Bamboo or Kerkeha (Arundinaria alpina) is found as homestead plantation as well as part of the natural vegetation cover in the area, albeit very sparsely. Korch (Erithrina brucei) is commonly grown as border demarcation plant in the area. Eucalyptus globulus is extensively grown in plantation, and some of the residents have become dependent on it for their livelihoods.

\subsection{Data used and image preprocessing}

The study utilized 27 topographic maps of the area at a scale of 1:50000 and 1:250000 dated 1984, geological maps at the scale of 1:250 000, and Landsat images of years 1985/6 (TM) and GLS 2005 (ETM+). Wet and dry season images of each year were acquired. Scenes were required to be of the same phenological cycle (dry or wet season) and have little or no cloud cover. The characteristics of the image data are shown in Table 1. All Landsat images were accessed free of charge from US Geological Survey (USGS) Center for Earth Resources Observation and Science (EROS) via http://glovis.usgs.gov/. All scenes supplied by the EROS Data Center had already been georeferenced to the Universal Transverse Mercator (UTM) map projection (Zone 37), WGS 84 datum and ellipsoid. The GLS 2005 Landsat 7 ETM+ image was processed to Standard Terrain Correction (Level 1T-precision and terrain correction) in the USGSEROS using the Level 1 Product Generation System (LPGS) (Williams, 2009). The Landsat 5 TM (1986) standard product is processed using the National Land Archive Production System (NLAPS). 
Table 1. Description of Landsat images used.

\begin{tabular}{lll|ll}
\hline & \multicolumn{2}{c|}{1986} & \multicolumn{2}{c}{2005} \\
\cline { 2 - 5 } & Dry Season & Wet Season & Dry Season & Wet Season \\
\hline Collection type & Landsat C. & Landsat C. & GLS collection & Landsat SLC-on \\
Satellite & Landsat 5 & Landsat 5 & Landsat 7 & Landsat 7 \\
Sensor & TM & TM & ETM+ & ETM+ \\
Path/Row & $169 / 053$ & $169 / 053$ & $169 / 053$ & $169 / 053$ \\
Acquisition date & 28 Feb 1986 & 9 Nov 1985 & 24 Nov 2005 & 15 Oct 2002 \\
Pixel spacing (m) & 28.5 & 28.5 & 30 & 30 \\
Sun Elevation & 44.52 & 50.425 & 50.7467 & 58.87 \\
Sun Azimuth & 128.79 & 132.73 & 141.585 & 125.86 \\
\hline
\end{tabular}

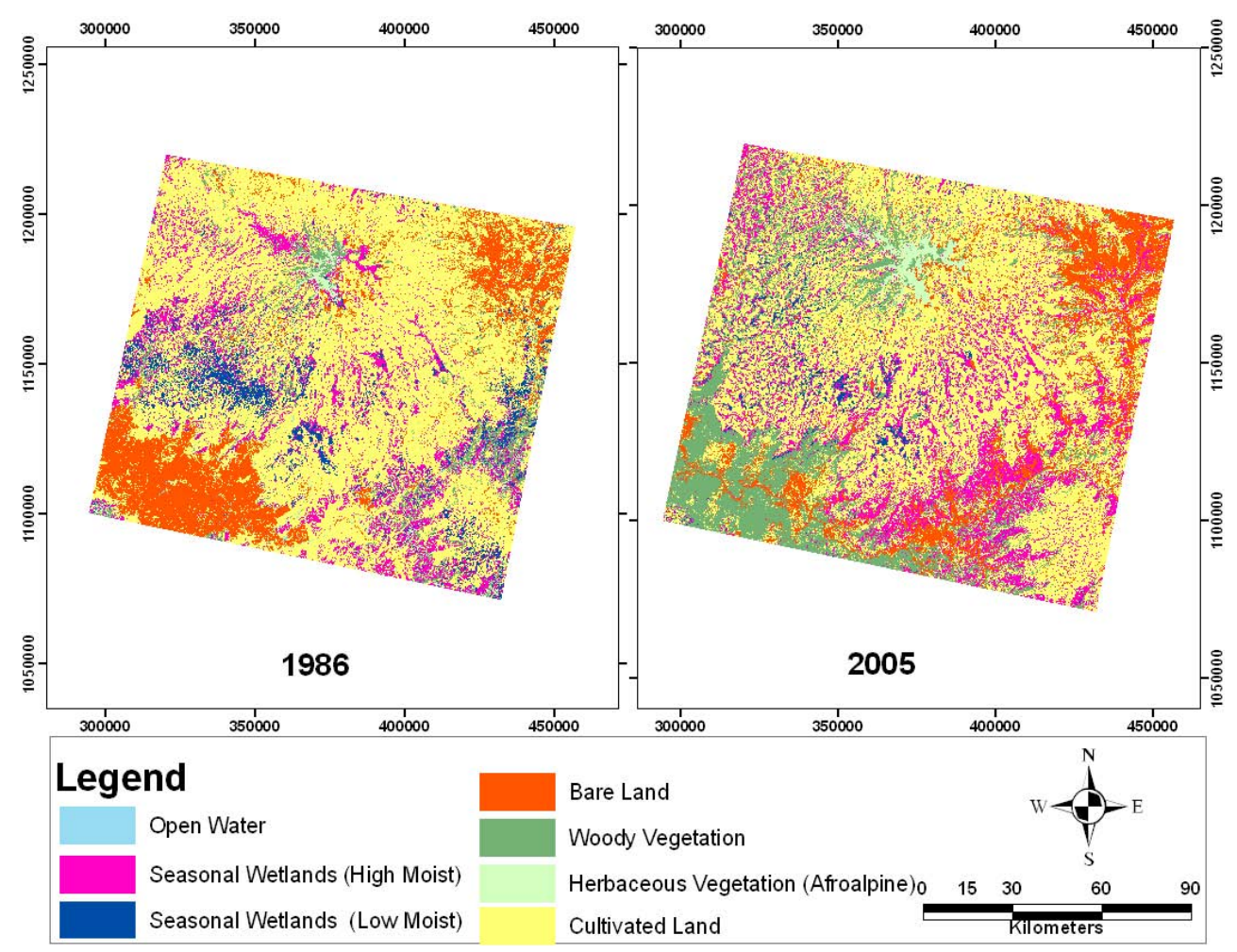

Fig. 2. Land covers in 1986 and 2005.

Sixteen-day Moderate Resolution Imaging Spectroradiometer (MODIS) derived Normalized Difference Vegetation Index (NDVI) at a resolution of $250 \mathrm{~m}$ gained from USGS, Land Processes Distributed Active Archive Center, Moderate Resolution Imaging Spectroradiometer (USGS Land DAAC MODIS version_005 EAF NDVI) to characterize the final wetland classes.

Several preprocessing methods were implemented before the classification and the change detection. These include geometric correction, radiometric correction, atmospheric correction, topographic normalization and temporal normalization. The importance of each preprocessing steps has been discussed extensively in the literature (e.g., Hill and Sturm, 1991; Han et al., 2007; Vicente-Serrano et al., 2008). The specific preprocessing steps followed in this research are briefly described below.

\subsubsection{Geometric correction}

Re-projection to the local level projection system was made (UTM, map projection; Clarke, 1880, Spheroid, and Adindan Datum). In some parts of the study area, there were significant discrepancies between the imageries and the underlying GIS base layers, which were extracted from high resolution 
SPOT-5 imagery. The misaligned scenes were georectified to the underlying base layers by using control points.

In this study, first the GLS 2005 Landsat 7 ETM+ was geometrically rectified using 25 control points taken from the topographic map at 1:50000 and 11 GPS points taken in the field. The other images were then registered to the ETM+ image with the same projection. An RMS error of less than 0.5 was achieved. The nearest neighbor resampling method was used to avoid altering the original pixel values of the image data. Because of the high incidence of varied topography in the study area, ortho-correction was found to be necessary and hence undertaken to further enhance the image geometry by accounting for the significant spatial distortion caused by relief displacement.

\subsubsection{Radiometric calibration}

The absolute radiometric correction method used in this paper involved a combination of cross-calibration method developed by Vogelman et al. (2001), with an atmospheric correction algorithm based on COST model (Chavez, 1996), denoted DOS3 by Song et al. (2001). Paolini et al. (2006) called this combination of methods "Vogelman-DOS3".

\section{Cross-calibration}

When using both Landsat TM and ETM+ images in studies that require radiometric consistency between images, special attention has to be paid to the differences in sensors response. Previous studies have demonstrated significant differences in the radiometric response between Landsat ETM+ and Landsat TM spectral bands (Teillet et al., 2001; Vogelmann et al., 2001). To reduce these differences and ensure image intercomparability, a cross-calibration was needed (Paolini et al., 2006; Vicente-Serrano et al., 2008). In the cross-calibration procedure, the Landsat TM images DN (DN5) were first converted to the Landsat ETM+ DN (DN7) images using the equation developed by Vogelmann et al. (2001). After this conversion, the L5 TM DN is treated as L7 ETM+ DN, and L7 ETM+ gain, offset and ESUN values are used respectively for radiance and Top-Of-Atmosphere (TOA) reflectance.

\section{Conversion to at-sensor spectral radiance}

At-sensor spectral radiance was computed for the crosscalibrated Landsat 5-TM (1986 images) quantized calibrated pixel values in DNs and Landsat 7-ETM+ quantized calibrated pixel values in DNs using sensor calibration parameters published by Chander et al. (2009) and in image header file.

\subsubsection{Conversion to Top of Atmosphere (TOA) reflectance}

To correct for illumination variations (sun angle and EarthSun distance) within and between scenes, TOA reflectance for each band was calculated. This conversion is a very important step in the calculation of an accurate Normalized Difference Vegetation Index (NDVI) and other vegetation indices. Some of the parameters for the conversion are available in the image header files, while the exo-atmospheric irradiance values for Landsat 7 are published by Chander et al. (2009).

\subsubsection{Atmospheric correction}

TOA reflectance value does not take into account the signal attenuation by the atmosphere, which strongly affects the intercomparability of the satellite images taken on different dates. But atmospheric correction methods account for one or more of the distorting effects of the atmosphere and thereby convert the brightness values of each pixel to actual reflectances as they would have been measured on the ground.

Several atmospheric correction models have been developed to eliminate atmospheric effects to retrieve correct physical parameters of the earth's surface (e.g. Surface reflectance), including SMAC (Rahman and Dedieu, 1994), $6 \mathrm{~S}$ (Vermote et al., 1997), MODTRAN (Berk et al., 1999), ATCOR (Richter, 1996), and COST (Chavez, 1996). Despite the variety of available techniques, a fully image-based technique developed by Chavez (1996) known as the COST model that derives its input parameters from the image itself, has been proved to provide a reasonable atmospheric correction (Mahiny and Turner, 2007; Berberoglu and Akin, 2009). The COST atmospheric model was used to convert the atsensor spectral radiance to reflectance at the surface of the Earth.

\subsubsection{Topographic correction}

In mountainous regions such as Upper Blue Nile Basin, topographic effects that result from the differences in illumination due to the angle of the sun and the angle of terrain produce different reflectances for the same cover type. Hence, the classification process for rugged terrain is seriously affected by topography and needs careful treatment of the data (Hodgson and Shelley, 1994; Hale and Rock, 2003).

To reduce the topographic effects methods such as spectral-band Ratioing (Holben and Justice, 1980), application of a Lambertian model (Cosine Correction) (Smith et al., 1980) and application of a non-Lambertian (Minnaert Correction and C-correction) (Meyer et al., 1993) have been developed. The C-correction (Teillet et al., 1982) is chosen for this study to correct for uneven reflectance patterns, as Meyer et al. (1993) and Riaño et al. (2003) showed it to be the most effective method of reducing the topographic effects for Landsat imagery (McDonald et al., 2000). The cosine of the incident solar angle was calculated using the equation of Holben and Justice (1980) and Smith et al. (1980). The variables used in the equation were derived from a digital elevation 
Table 2. C-correction coefficients derived for the non-Lambertian corrected images.

\begin{tabular}{ccccccc}
\hline Band & 1 & 2 & 3 & 4 & 5 & 7 \\
\hline 2005 & 0.341 & 0.420 & 0.486 & 0.327 & 0.630 & 0.584 \\
1986 & 0.397 & 0.326 & 0.490 & 0.261 & 0.597 & 0.498 \\
\hline
\end{tabular}

model (DEM), and sun orientation information was gathered from image header data. The Regress module in IDRISI calculated the C-correction coefficient by regressing actual radiance values of each image band (the dependent variable) and cosine of the incident solar angle (the independent variable). The derived C-correction coefficients (Table 2) were then used as parameters to normalize both images for topographic effects.

Besides visual analysis, the evaluation of topographic correction was based on the computation of $R^{2}$-values for the linear regression between corrected data and cosine of the incident solar angle. Since the topographic impact varies with wavelength and is most prevalent in the near-infrared spectral region, a reduction in the $R^{2}$-value for the near-infrared band was observed ( 0.214 to 0.008 for the 1986 image and 0.291 to 0.0342 for the 2005 image). This indicates the effectiveness of the non-Lambertian C-correction.

\subsubsection{Temporal normalization}

Vicente-Serrano et al. (2008) recommended an additional step (temporal normalization) to completely remove nonsurface noise and improve temporal homogeneity of satellite imagery. Therefore 9 reservoir sites and 5 bare sites were used to normalize the $2005 \mathrm{ETM}+$ image (slave) with respect to 1986 TM image (reference). The resulting normalization equation is shown in Table 3.

\subsubsection{Image classification}

A hybrid supervised/unsupervised classification approach was used to classify the images. This approach involved: (1) unsupervised classification using ISODATA (Iterative Self-Organizing Data Analysis) to determine the spectral classes into which the image resolved; (2) using the spectral clusters ground truth (reference data) were collected to associate the spectral classes with the cover types observed at the ground for the 2005 image and for the 1986 image reference data were collected from the 1984 Topographic map (1:50 000 scale); and (3) classification of the entire image using the maximum likelihood algorithm. A hierarchical class grouping was adopted to label and identify the classes (Thenkabail et al., 2005) in both the wet and dry season images. First, the unsupervised ISODATA clustering was used. 25 initial classes were found and then after a rigorous identification and labeling process the original 25 classes were progressively reduced to 17,7 and 4 classes by using ground truth data. Ground truth data on spatial location, land cover types, soil moisture status, and topographic characteristics were collected from selected sample sites during the period from June 2009 to March 2010. Stratified random sampling design was adopted for the selection of 342 point sample sites. Stratification was based on the accessibility of the sites. Spatial locations were obtained using a GPS (Global Positioning System).

To assist within class identification process in the unsupervised classes, the at-sensor reflectance based NDVI (Normalized Difference Vegetation Index) values were calculated. Wetlands with covers of barren lands and/or with sparse vegetation have lower NDVI values as a result of soil moisture that is relatively higher than the surrounding areas. When wetlands have vegetation or crops the NDVI will vary depending on vegetation density and vigor.

At-sensor reflectance based Tasseled Cap wetness values (Huang et al., 2002) were also calculated for both Landsat ETM+ (2005) and cross-calibrated TM (1986) images using the Raster Calculator in ArcGIS 9.3. Tasseled Cap coefficients of 0.2626 (B1), 0.2141 (B2), 0.0926 (B3), 0.0656 (B4), -0.7629 (B5), and -0.5388 (B7) were used. The Density Slice tool in the ENVI 4.5 software was used to select data ranges and colors for highlighting wetland/non-wetland areas from the spectral classes.

\subsubsection{Post-classification processing and assessment}

A variety of change detection techniques have been developed (Yuan et al., 1998; Lu et al., 2004). Each of them has its own merit and no single approach is optimal and applicable to all cases. Yuan et al. (1998) divide the methods for change detection and classification into pre-classification and postclassification techniques. In this paper post-classification comparison change detection approach which compares two independently produced classified land use/cover maps from images of two different dates (Jensen, 2005) was used. Other studies (Mas, 1999; Civco et al., 2002) demonstrated that it was the most accurate measure of change. The principal advantage of post-classification is that the two dates of imagery are separately classified; hence it does not require data normalization between two dates (e.g. Singh, 1989). The other advantage of post-classification is to provide information about the nature of change (including trajectories of change) (Song et al., 2001; Coppin et al., 2004).

The accuracy of the classification results was assessed by computing the confusion matrix (error matrix) which compares the classification result with ground truth information. 17 classes were identified using the hybrid supervised/unsupervised classification. Classes of different spectral patterns but the same information classes were selectively combined in the classified images and finally reduced to 7 classes. Majority analysis was also performed to change spurious pixels within a large single class to that 
Table 3. Image normalization regression models developed for Choke area image.

\begin{tabular}{cccc}
\hline & Regression models & $r^{2}$ & Normalization targets \\
\hline 1986 TM B2 & $=-25.2+1.03(2005$ ETM+ B2) & 0.981 & 8 wet and 4 dry \\
1986 TM B3 & $=-26.4+1.03(2005$ ETM+ B3) & 0.993 & 9 wet and 5 dry \\
1986 TM B4 & $=-21.7+0.98(2005$ ETM+ B4) & 0.987 & 8 wet and 5 dry \\
\hline
\end{tabular}

Table 4. Descriptions of the land cover classes identified in the Mt. Choke range.

\begin{tabular}{lll}
\hline Class Code & Class Name & Description \\
\hline OW & open water & Ponds or stagnant water \\
SWL & seasonal wetlands with low moisture & wetlands, grasslands covered \\
& (Islam et al., 2008) & with less vigorous grass - low NDVI \\
SWH & seasonal wetlands with high moisture & wetlands, grass lands and very moist farmlands or \\
& (Islam et al., 2008) & irrigated land (high vegetation cover and high NDVI) \\
AF & afro alpine herbaceous vegetation & afro alpine grasses \\
WV & woody vegetation & shrubs, bushes, plantations \\
CL & cultivated land & rainfed agriculture \\
BL & bare land & exposed soil and rock \\
\hline
\end{tabular}

class. Finally, a detailed tabulation of changes in wetland and non-wetland classes between 1986 and 2005 classification images were compiled by post-classification comparison

\section{Results and discussion}

The study area was classified into seven classes: three wetland classes and four non-wetland classes. The description for each class is given in Table 4. Although riparian vegetation cover defines one type of wetland, because of the limitation of the classification method used it was classified as woody vegetation.

A Confusion Matrix was computed to assess the accuracy of the classification by comparing the classification results with ground truth information. From the Confusion Matrix report $94.1 \%$ and $93.5 \%$ overall accuracy for the 1986 and 2005 imageries were attained, respectively. The overall accuracy was calculated by summing the number of pixels classified correctly and dividing by the total number of pixels. An overall accuracy level of $85 \%$ was adopted as representing the cutoff point between acceptable and unacceptable results according to Anderson et al. (1976). The Confusion Matrix also reports the Kappa Coefficient $(k)$ which is another measure of the accuracy of the classification (Cohen, 1960). The $k$ values for the 1986 and 2005 image classification were 0.908 and 0.913 , respectively. The values can range from -1 to +1 . However, since there should be a positive correlation between the remotely sensed classification and the reference data, positive $k$ values indicate the goodness of the classification. Landis and Koch (1977) character- ized the possible ranges for $k$ into three groupings: a value greater than 0.80 (i.e., $80 \%$ ) represents strong agreement; a value between 0.40 and 0.80 (i.e., 40-80\%) represents moderate agreement; and a value below 0.40 (i.e., 40\%) represents poor agreement.

The accuracies for both the 1986 and 2005 image classification were considered good enough to apply postclassification change detection analysis. Basically this analysis focuses on the initial state classification changes (1986 image). For each initial state class (1986), the postclassification comparison technique identifies the classes into which those pixels changed in the final state image (2005).

\subsection{Space-time dynamics of non-wetland land cover types}

Table 5 lists the initial state classes in the columns, the final state classes in the rows and the unchanged areas in the diagonal cells. For each initial state class (i.e., each column), the table indicates how these pixels were classified in the final state image. A total of $891 \mathrm{~km}^{2}$ was classified as woody vegetation in the initial state image (1986), while $2965 \mathrm{~km}^{2}$ was classified as woody vegetation in the final state image (2005) (Table 5). $2074 \mathrm{~km}^{2}$ woody vegetation cover has increased over the 20 years studied. This is mainly attributed to the increase in Eucalyptus plantation in the area (e.g. Raba Forest and Wildlife Reserve). After significant deforestation in the past the scarcity of wood for fuel and other uses has forced the local people to plant trees (Bewket, 2003). About $46 \%$ $\left(1351 \mathrm{~km}^{2}\right)$ of the existing woody vegetation has come from 
Table 5. Change detection statistics.

\begin{tabular}{|c|c|c|c|c|c|c|c|c|c|}
\hline & & \multicolumn{8}{|c|}{ Initial State Image (1986) } \\
\hline & & OW & SWH & SWL & $\mathrm{AF}$ & WV & CL & BL & Class Total \\
\hline$\frac{6}{6}$ & OW & 15.4 & 25.0 & 0.5 & 0.0 & 0.0 & 0.1 & 5.4 & 46.4 \\
\hline ర్త్ర & SWH & 27.3 & 748.7 & 275.3 & 52.2 & 122.9 & 1621.7 & 151.5 & 2999.6 \\
\hline 0 & SWL & 0.0 & 132.3 & 111.5 & 15.1 & 10.9 & 64.0 & 5.7 & 339.5 \\
\hline$\Xi$ & $\mathrm{AF}$ & 0.0 & 96.0 & 13.7 & 79.9 & 49.9 & 47.3 & 12.4 & 299.2 \\
\hline$\Xi$ & WV & 17.0 & 301.4 & 59.3 & 34.1 & 328.7 & 1351.0 & 873.2 & 2964.7 \\
\hline 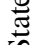 & CL & 6.9 & 632.8 & 422.0 & 38.3 & 307.2 & 6687.3 & 674.3 & 8768.8 \\
\hline$\approx$ & $\mathrm{BL}$ & 2.2 & 104.7 & 64.0 & 7.6 & 71.2 & 1002.7 & 772.1 & 2024.5 \\
\hline 梣 & Class Total & 68.8 & 2040.9 & 946.3 & 227.2 & 890.8 & 10774.1 & 2494.6 & \\
\hline
\end{tabular}

$\mathrm{OW}=$ open water, $\mathrm{SWH}=$ seasonal wetlands with high moisture, $\mathrm{SWL}=$ seasonal wetlands with low moisture, $\mathrm{AF}=$ afro alpine herbaceous vegetation, $\mathrm{WV}=$ woody vegetation, $\mathrm{CL}=$ cultivated land, $\mathrm{BL}=$ bare land

cultivated land and $30 \%\left(873.2 \mathrm{~km}^{2}\right)$ from bare land categories. Since the productive capacity of the the cultivated land is being threatened by the loss of nutrients through erosion, farmers in the area are looking for another option because they could not cope with declining crop yields. Every year more and more agricultural land is being converted into Eucalyptus forest plantation which ensures income security for local residents. This trend in land-use and landcover change is altering the soil (Bewket and Stroosnijder, 2003) and hydrologic (Bewket and Sterk, 2005) characteristics of upland watersheds of the Choke Mountain range. This may also influence the livelihoods of the population living in downstream areas by changing critical watershed functions (e.g. availability of water during the dry season).

\subsection{Space-time dynamics of wetlands}

In the initial state (1986) image, $946.3 \mathrm{~km}^{2}$ of land was classified as seasonal wetlands with low moisture, but only $339.5 \mathrm{~km}^{2}$ of land was classified as seasonal wetlands with low moisture in the final state image. This means a total of $607 \mathrm{~km}^{2}$ of seasonal wetlands with low moisture were lost and/or converted to another land cover/use type during the period 1986 to 2005 (Table 5). Out of the $946.3 \mathrm{~km}^{2}$ of seasonal wetlands with low moisture class in the initial state image, only $111.5 \mathrm{~km}^{2}(12 \%)$ remain unchanged and $835 \mathrm{~km}^{2}$ $(88 \%)$ of the initial class has been converted and this makes the class most dynamic (unstable) of all observed land cover types. About $422 \mathrm{~km}^{2}(\sim 51 \%), 275.3 \mathrm{~km}^{2}(\sim 33 \%), 64 \mathrm{~km}^{2}$ $(8 \%)$, and $59.3 \mathrm{~km}^{2}(7 \%)$ of the previous seasonal wetlands with low moisture cover were converted to cultivated land, seasonal wetland with high moisture, bare land, and woody vegetation respectively. Every year $21 \mathrm{~km}^{2}$ of seasonal wetlands with low moisture land cover types are converted to cultivated land. This indicates that the experience of wetland cultivation which is common in south-wet Ethiopia (Dixon and Wood, 2003; Dixon, 2002) is also practiced in Choke Mountain range. With the increase in population pressure

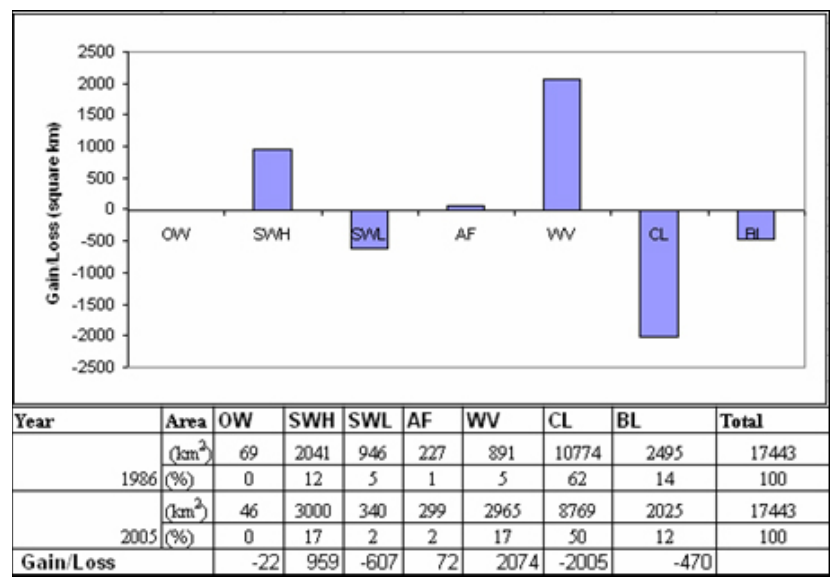

Fig. 3. Proportions of land cover types in 1986 and 2005.

and shortage of land, government considers wetland cultivation as a remedy to address the food needs (Wood, 1996; World Bank, 2001). As a result, seasonal wetlands with low moisture have come under pressure.

Again based on Table 5, $2040.9 \mathrm{~km}^{2}$ of land was classified as seasonal wetlands with high moisture in the initial state image, and $2999.6 \mathrm{~km}^{2}$ of land was classified as seasonal wetlands with high moisture in the final state image. A total gain of $959 \mathrm{~km}^{2}$ in the seasonal wetlands with high moisture land cover was observed (Fig. 3). Out of $2999.6 \mathrm{~km}^{2}$ seasonal wetland with high moisture class, $54 \%\left(1621.7 \mathrm{~km}^{2}\right)$ have come from cultivated land, $9 \%\left(275.3 \mathrm{~km}^{2}\right)$ have come from seasonal wetlands with low moisture class and $25 \%$ $\left(748.7 \mathrm{~km}^{2}\right)$ remain unchanged. The contribution of cultivated land to the increase in the seasonal wetland with high moisture class is significant $(54 \%)$. Since the gain is mostly from classes initially classified as cultivated land, the increase in moist farmlands (irrigated land) caused the increase in the seasonal wetland with high moisture class. This is related to the expansion of small scale irrigation (man-made 


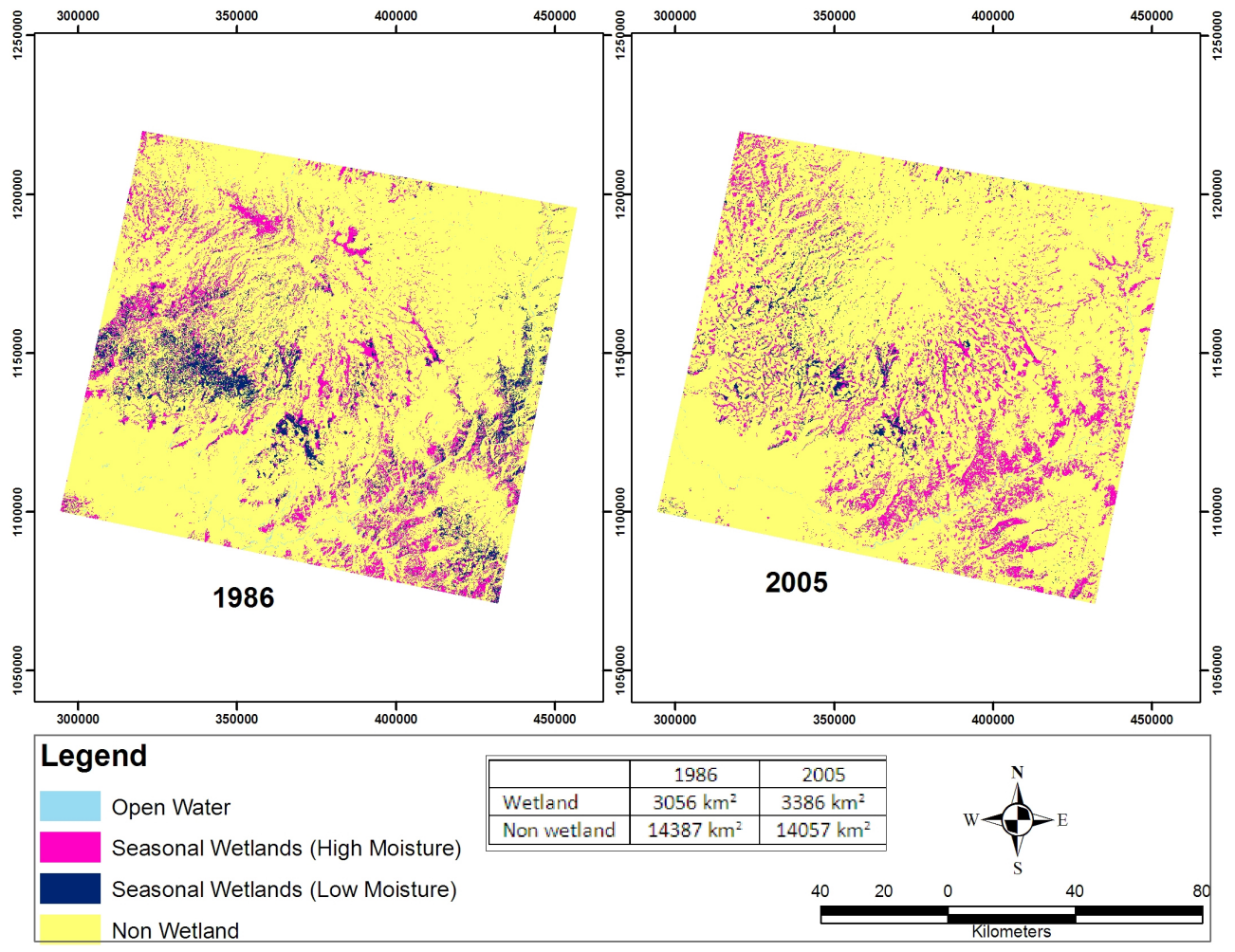

Fig. 4. Spatial distribution of wetland and non wetland.

wetland) in the 1990s. Jedeb irrigation project located at Yewla village (East Gojam) constructed in 1996 by diverting Jedeb river through a diversion weir $\left(11^{\circ} 22^{\prime} \mathrm{N}\right.$ and $\left.37^{\circ} 33^{\prime} \mathrm{E}\right)$ is one of the best examples.

In the initial state (1986) image, $68.8 \mathrm{~km}^{2}$ of land was classified as open water and $46.4 \mathrm{~km}^{2}$ of land was classified as open water in the final state image. This means a total of $22.4 \mathrm{~km}^{2}$ of open water wetlands were lost and converted to another land cover/use type during the period 1986 to 2005 . About $40 \%\left(27.3 \mathrm{~km}^{2}\right)$ of the initial open water class were converted to seasonal wetlands with high moisture, $25 \%\left(17 \mathrm{~km}^{2}\right)$ to bare land and $22 \%\left(15.4 \mathrm{~km}^{2}\right)$ remain unchanged. According to farmers of the locality Wezem pond and Ginchira pond located in Muga watershed of Choke Mountain are now being converted to bare land. This was also substantiated by field observation. In contrast, Bahirdar pond (Fig. 5) at Yenebirna village in Chemoga watershed showed a gradual increase through time (Table 6). To analyze this situation 10 satellite images (5 on dry season and 5 on wet season) were taken and the size of Bahirdar pond was determined. The observed smallest size (4.2 ha) could be because of the 1986 drought occurred throughout Ethiopia. This indicated that the condition of wetlands of the area is dependent on climatic factors beyond human influences. The increasing trend of rainfall of the area around the pond (Fig. 6) associated with increasing runoff and sediment inflow from the surrounding watershed could be one of
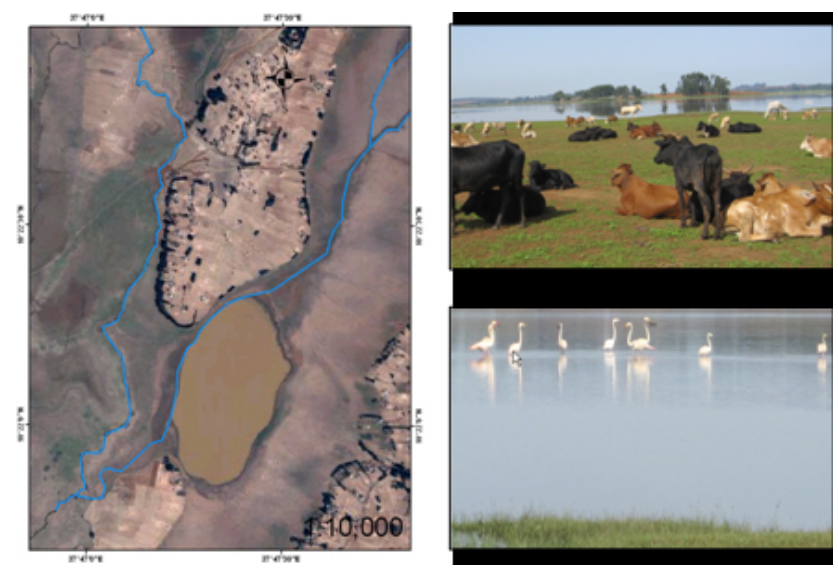

Fig. 5. Open water wetland at Yenebrna village (East Gojam).

the reasons for the gradual increase of the pond. A study by McHugh et al. (2007) explained one example from north-east Ethiopia for the case of Hara swamp.

\subsection{Characterization of wetlands}

Although Landsat (TM and ETM+) has 16-day repeat cycle, these 16-day images are not available for the period 20012009. Therefore, the class characteristics were studied using Moderate Resolution Imaging Spectroradiometer (MODIS), 
Table 6. Time-series of pond size.

\begin{tabular}{llllll}
\hline & 1984 & 1986 & 1995 & 2000 & $2005 / 6$ \\
\hline Dry season & 7 ha & 4.2 ha & 23.1 ha & 34 ha & 35 ha \\
Wet season & 7.4 ha & 6.2 ha & 39 ha & 39 ha & 41 ha \\
Source & Landsat TM & Landsat TM & Landsat TM & Landsat ETM+ & ASTER \\
\hline
\end{tabular}

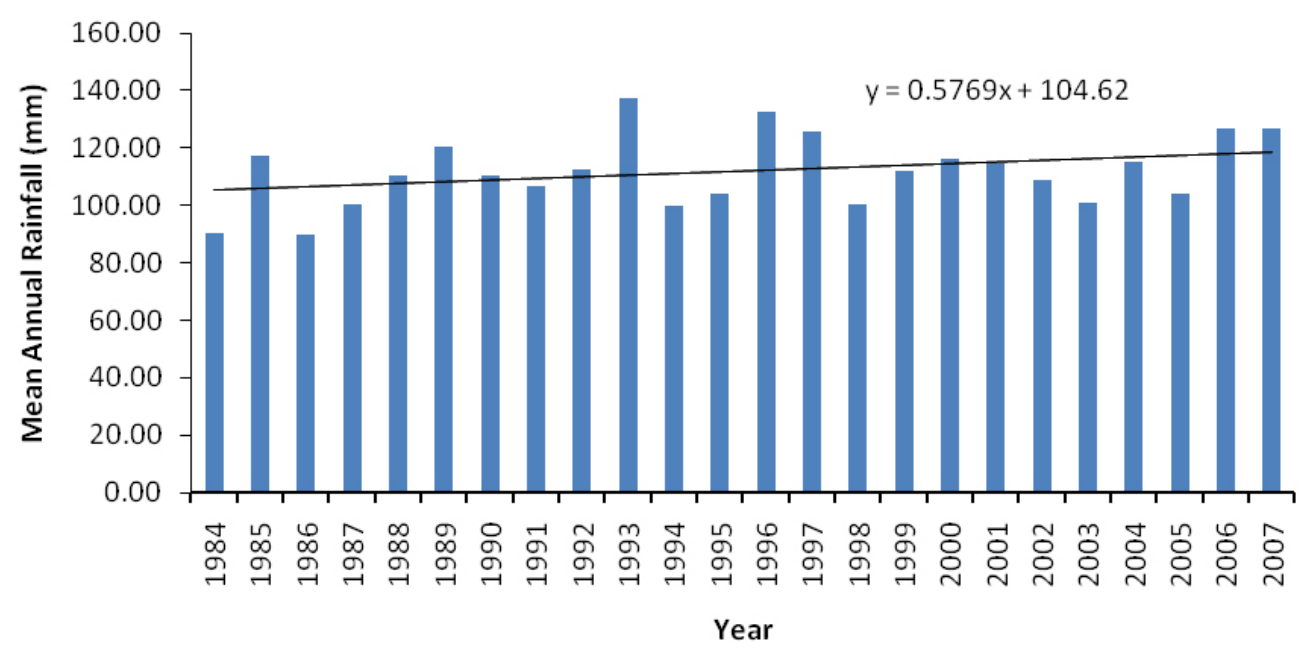

Fig. 6. The mean annual rainfall trend at Debre Markos station.

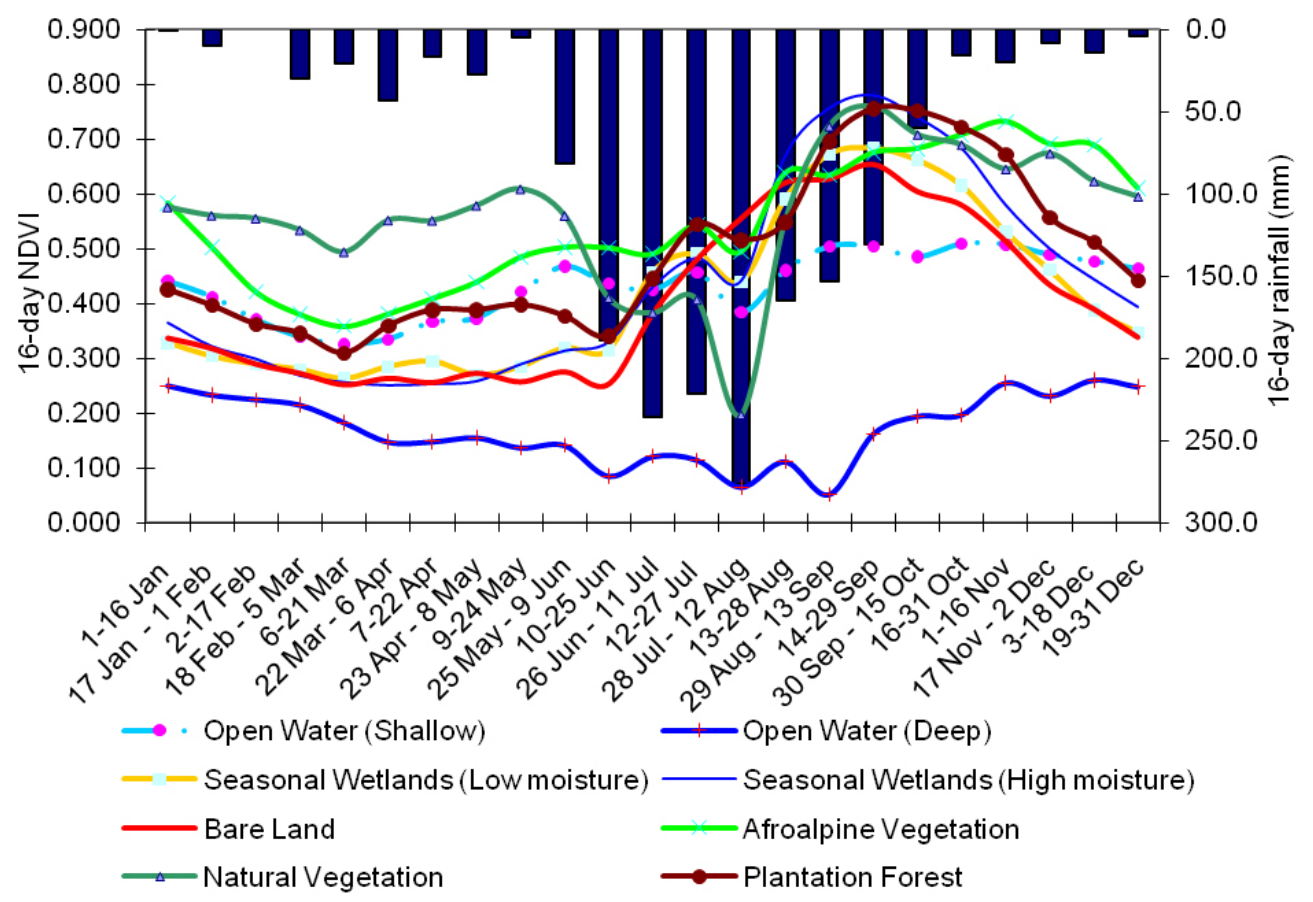

Fig. 7. The time-series characteristics of the wetlands and non wetlands (Mean 16-day 4 annual NDVI and rainfall for the period 2001 to 2009). 
16-day Normalized Difference Vegetation Index (NDVI) at a resolution of $250 \mathrm{~m}$ gained from United States Geological Survey, Land Processes Distributed Active Archive Center.

Deep open water shows lower NDVI values than the other wetland classes throughout the year. Because open water features have lower near infrared reflectance. The standard deviation of the response of open water to NDVI is the least (0.06) among the 7 land cover lasses. Indicating that a more or less constant response to NDVI except during rainy season. The increase in runoff with increase in trapped sediment during rainy season may change the normal NDVI response. The highest variance $(0.18)$ is observed in seasonal wetland with high moisture land cover classes. These classes show higher NDVI values in September and lower values during the period 22 March to 6 April. Seasonal wetlands with high moisture and low moisture classes are clearly distinct during the period from end of August to December.

The NDVI time-series class characteristics follows the rainfall trend (Fig. 7); vegetation begins to gain vigor in beginning of September and remains at high vigor until November while the rainfall reaches maximum during 28 July to 12 August. Previous studies have investigated the lag and cumulative effect of rainfall on vegetation in semi-arid and arid regions of Africa (Martiny et al., 2006; Wagenseil and Samimi, 2006) and humid regions of Africa (Onema and Taigbenu, 2009). However, this lag effect of rainfall can not be observed in open water.

\section{Conclusions}

The study demonstrated the use of remote sensing techniques to delineate headwater wetlands from non-wetlands and determine the dynamics over large areas of Choke Mountains with the overall accuracy of $94.1 \%$ and $93.5 \%$ and Kappa Coefficient of 0.908 and 0.913 for the 1986 and 2005 imageries, respectively. Therefore, ground-based wetland surveying for large area, especially for small wetlands is a very time consuming and ineffective process. The use of Remote Sensing and GIS techniques in wetland mapping reduces cost and enhances the accuracy. Creating radiometrically consistent image data through (Vogelman-DOS3) methods before applying hybrid supervised/unsupervised classification was found to be effective in wetland mapping. However the application of technique to Landsat images was not effective in mapping riparian vegetation as wetland. To undertake a more focused wetland management plan implementation the use of mandatory environmental characteristics (vegetation, soil, and hydrology) for wetland detection is still important.

Four major trajectories of change that were observed: (1) from seasonal wetlands with low moisture to cultivated land, (2) from cultivated land to woody vegetation (plantation), (3) from open water to bare land, and (4) from bare land to cultivated land. In general, $607 \mathrm{~km}^{2}$ of seasonal wetland with low moisture and $22.4 \mathrm{~km}^{2}$ of open water are lost in the study area over the 20 years considered. This is one indication of future deterioration in wetland condition. This calls for wetland conservation and rehabilitation through incorporating wetlands into watershed management plans so as to make wetlands continue providing their multiple functions which include flood control, stream-flow moderation, groundwater recharge, sediment detention, and pollutant retention. Further research on specific wetland spots is needed for accurate inventories of wetlands and to explore the reasons why and how wetlands are changing.

Acknowledgements. The study was carried out as a project within a larger research program called "In search of sustainable catchments and basin-wide solidarities in the Blue Nile River Basin", which is funded by the Foundation for the Advancement of Tropical Research (WOTRO) of the Netherlands Organization for Scientific Research (NWO), UNESCO-IHE and Addis Ababa University. The authors are grateful to US Geological Survey (USGS) Center for Earth Resources Observation and Science (EROS) and Land Processes Distributed Active Archive Center (Land DAAC) for providing research data free of charge.

Edited by: A. Melesse

\section{References}

Anderson, J. R., Hardy, E. E., Roach, J. T., and Witmer, R. E.: A land use and land cover classification system for use with remote sensor data, USGS Professional Paper 964, Sioux Falls, SD, USA, 1976.

Baker, C., Lawrence, R., Montagne, C., and Patten, D.: Mapping wetlands and riparian areas using Landsat ETM+ imagery and decision-tree-based models, Wetlands, 26, 465-474, 2006.

BCEOM: Abbay River Basin Integrated Development Master PlanPhase 2 - Water Resources - Climatology, Ministry of Water Resources, Addis Ababa, 144 pp., 1998a.

BCEOM: Abbay River Basin Integrated Development Master PlanPhase 2 - Water Resources - Hydrology, Ministry of Water Resources, Addis Ababa, 144 pp., 1998 b.

BCEOM: Abbay River Basin Integrated Development Master PlanPhase 2 - Land Resources Development - Reconnaissance Soils Survey, Ministry of Water Resources, Addis Ababa, 208 pp., 1998c.

Berberoglu, S. and Akin, A.: Assessing different remote sensing techniques to detect land use/cover changes in the eastern Mediterranean, Int. J. Appl. Earth Obs., 11, 46-53, 2009.

Berk, A., Anderson, G. P., Bernstein, L. S., Acharya, P. K., Dothe, H., Matthew, M. W., Adler-Golden, S. M., Chetwynd, J. H., Richtsmeier, S. C., Pukall, B., Allred, C. L., Jeong, L. S., and Hoke, M. L.: MODTRAN4 radiative transfer modeling for atmospheric correction, in: Proceedings of SPIE Optical Spectroscopic Techniques and Instrumentation for Atmospheric and Space Research III, Denver, Co, USA, 18 July 1999, 1999.

Bewket, W.: Household level tree planting and its implications for environmental management in the north-western highlands of Ethiopia: A case study in the Chemoga watershed, Blue Nile basin, Land Degrad. Dev., 14, 377-388, 2003. 
Bewket, W. and Sterk, G.: Dynamics in land cover and its effect on stream flow in the Chemoga watershed, Blue Nile basin, Ethiopia, Hydrol. Process., 19, 445-458, 2005.

Bewket, W. and Stroosnijder, L.: Effects of agro-ecological land use succession on soil properties in Chemoga watershed, Blue Nile basin, Ethiopia, Geoderma, 111, 85-98, 2003.

Bewket, W. and Teferi, E.: Assessment of Soil Erosion Hazard and Prioritization for Treatment at the Watershed Level: Case Study in the Chemoga Watershed, Blue Nile Basin, Ethiopia, Land Degrad. Dev., 20, 609-622, 2009.

Callan, O. and Mark, A. F.: Using MODIS data to characterize seasonal inundation patterns in the Florida Everglades, Remote Sens. Environ., 112, 4107-4119, 2008.

Civco, D. L., Hurd, J. D., Wilson, E. H., Song, M., and Zhang, Z.: A Comparison of Land Use and Land Cover Change Detection Methods, in: Proceedings of 2002 ASPRS-ACSM Annual Conference and FIG XXII Congress, Washington, D.C., 22-26 April 2002, 12 pp., 2002.

Chander, G., Markham, B. L., and Helder, D. L.: Summary of current radiometric calibration coefficients for Landsat MSS, TM, ETM+, and EO-1 ALI sensors, Remote Sens. Environ., 113, 893-903, 2009.

Chavez, P. S.: Image-based atmospheric corrections-revisited and improved, Photogramm. Eng. Rem. S., 62, 1025-1036, 1996.

Cohen, J.: A coefficient of agreement for nominal scales, Educ. Psychol. Meas., 20, 37-40, 1960.

Colby, J. D.: Topographic normalization in rugged terrain, Photogramm. Eng. Rem. S., 62, 151-161, 1991.

Conway, D.: From headwater tributaries to international river: Observing and adapting to climate variability and change in the Nile Basin, Global Environmental Change, 15, 99-114, 2005.

Coppin, P., Jonckheere, I., Nackaerts, K., Muys, B., and Lambin, E.: Digital change detection methods in ecosystem monitoring: A review, Int. J. Remote Sens., 25, 1565-1596, 2004.

Dixon, A. B.: The hydrological impacts and sustainability of wetland drainage cultivation in Illubabor, Ethiopia, Land Degrad. Dev., 13, 17-31, 2002.

Dixon, A. B. and Wood, A. P.: Wetland cultivation and hydrological management in eastern Africa: Matching community and hydrological needs through sustainable wetland use, Nat. Resour. Forum, 27, 117-129, 2003.

Ehrenfeld, J. G.: Evaluating wetlands within an urban context, Ecol. Eng., 15, 253-265, 2000.

Finlayson, C. M., Davidson, N. C., Spiers, A. G., and Stevenson, N. J.: Global wetland inventory - current status and future priorities, Mar. Freshwater Res., 50, 717-727, 1999.

Frazier, S. P. and Page, J. K.: Water body detection and delineation with Landsat TM data, Photogramm. Eng. Rem. S., 66, 14611467, 2000.

Hadjimitsis, D. G., Clayton, C. R. I., and Hope, V. S.: An assessment of the effectiveness of atmospheric correction algorithms through the remote sensing of some reservoirs, Int. J. Remote Sens., 25, 3651-3674, 2004.

Hailu, A., Wood, A. P., and Dixon, A. B.: Interest groups, local knowledge and community management of wetland agriculture in South-West Ethiopia, Int. J. Ecol. Environ. Sci., 29, 55-63, 2003.

Hale, S. R. and Rock, B. N.: Impact of Topographic Normalization on Land-Cover Classification Accuracy, Photogramm. Eng.
Rem. S., 69(7), 785-791, 2003.

Han, T., Wulder, M. A., White, J. C., Coops, N. C., Alvarez, M. F., and Butson, C.: An efficient protocol to process Landsat images for change detection with tasselled cap transformation, IEEE Geosci. Remote S., 4, 147-151, 2007.

Hill, J. and Sturm, B.: Radiometric correction of muli-temporal Thematic Mapper data for use in agricultural land-cover classification and vegetation monitoring, Int. J. Remote Sens., 12(7), 1471-1491, 1991.

Hodgson, M. E. and Shelley, B. M.: Removing the topographic effect in remotely sensed imagery, ERDAS Monitor, 6, 4-6, 1994.

Holben, B. N. and Justice, C. O.: The topographic effect on spectral response from nadir-pointing sensors, Photogramm. Eng. Rem. S., 46, 1191-1200, 1980.

Huang, C., Wylie, B., Yang, L., Homer, C., and Zylstra, G.: Derivation of a Tassled Cap transformation based on Landsat and atsatellite reflectance, Int. J. Remote Sens., 23, 1741-1748, 2002.

Islam, Md. A., Thenkabail, P. S., Kulawardhana, R. W., Alankara, R., Gunasinghe, S., Edussriya, C., and Gunawardana, A.: Semiautomated methods for mapping wetlands using Landsat ETM+ and SRTM data, Int. J. Remote Sens., 29, 7077-7106, 2008.

Jensen, J. R.: Introductory digital image processing: A remote sensing perspective, 3rd Edn., Prentice Hall, Upper Saddle River, NY, 526 pp., 2005.

Jensen, J. R., Narumalani, S., Weatherbee, O., and Mackey, H. E.: Measurement of Seasonal and Yearly Cattail and Waterlily Changes Using Multidate SPOT Panchromatic Data, Photogramm. Eng. Remote S., 59, 519-525, 1993.

Koeln, G.: How wet is this wetland? Earth Observation Magazine, July/August, 36-39, 1992.

Landis, J. and Koch, G.: The measurement of observer agreement for categorical data, Biometrics, 33, 159-174, 1977.

Lemma, B.: Human intervention in two lakes: Lessons from Lakes Alemaya and Hora-Kilole, in: Proceedings of the National Consultative workshop on the Ramsar Convention and Ethiopia, 1819 March 2004, Addis Ababa, Ethiopia, 2004.

Loiselle, S., Cózar, A., van Dam, A. A., Kansiime, F., Kelderman, P., Saunders, M., and Simonit, S.: Development of tools for wetland ecosystem resource management in East Africa, in: Wetlands and Natural Resource Management: Ecological Studies, edited by: Verhoeven, J. T. A., Beltman, B., Bobbink, R., and Whigham, D. F., Springer, Berlin, 97-122, 2006.

Lu, D., Mausel, P., Brondizio, E., and Moran, E.: Change Detection Techniques, Int. J. Remote Sens., 25, 2365-2407, 2004.

Mac, M. J., Opler, P. A., Puckett Haecker, C. E., and Doran, P. D.: Status and trends of the nation's biological resources, 2 vol., US Department of the Interior, US Geological Survey, Reston, Va., 1998, http://www.nwrc.usgs.gov/sandt/index.html, last access: 24 June 2010.

Mahiny, A. S. and Turner, B. J.: A comparison of four common atmospheric correction methods, Photogramm. Eng. Rem. S., 73, 361-368, 2007.

Markham, B. L. and Barker, J. L.: Landsat MSS and TM postcalibration dynamic ranges, exoatmospheric reflectances and atsatellite temperatures, EOSAT Landsat Technical Notes, 1, 3-8, 1986.

Martiny, N., Camberlin, P., Richard, Y., and Philippon, N.: Compared regimes of NDVI and rainfall in semi-arid regions of Africa, Int. J. Remote Sens., 23, 5201-5223, 2006. 
Mas, J. F.: Monitoring land-cover changes: a comparison of change detection techniques, Int. J. Remote Sens., 20, 139-152, 1999.

Matthews, E. and Fung, I.: Methane emissions from natural wetlands: global distribution, area, and environmental characteristics of sources, Global Biogeochem. Cy., 1, 61-86, 1987.

McDonald, E. R., Wu, X., Caccetta, P. A., and Campbell, N. A.: Illumination Correction of Landsat TM Data in South East NSW, in: Proceedings of the Tenth Australasian Remote Sensing and Photogrammetry Conference, Adelaide, Australia, 21-25 August, 2000.

McHugh, O. V., McHugh, A. N., Eloundou-Enyegue, P. M., and Steenhuis, T. S.: Integrated Qualitative Assessment of Wetland Hydrological and Land Cover Changes in a Data Scarce Dry Ethiopian Highland Watershed, Land Degrad. Dev., 18, 643-658, 2007.

McKergow, L. A., Gallant, J. C., and Dowling, T. I.: Modelling wetland extent using terrain indices, Lake Taupo, NZ, in: Proceedings of MODSIM 2007 International Congress on Modelling and Simulation, Modelling and Simulation Society of Australia and New Zealand, December 2007, 74-80, 2007.

Meyer, P., Itten, K., Kellenberger, T., Sandmeier, S., and Sandmeier, R.: Radiometric corrections of topographically induced effects on Landsat TM data in an alpine environment, ISPRS J. Photogramm., 48(4), 17-28, 1993.

Mohamed, Y. A., van den Hurk, B. J. J. M., Savenije, H. H. G., and Bastiaanssen, W. G. M.: Hydroclimatology of the Nile: results from a regional climate model, Hydrol. Earth Syst. Sci., 9, 263278, doi:10.5194/hess-9-263-2005, 2005.

Moser, M., Prentice, C., and Frazier, S.: A global overview of wetland loss and degradation, in: Proceedings of the 6th Meeting of the Conference of Contracting Parties of the Ramsar Convension, Brisbane, Australia, 19-27 March 1996, 21-31, 1996.

Mulugeta, M.: Socio-economic Determinants of Wetland use in the Metu and Yayu-Hurumu Weredas of Illubabor Zone, in: Sustainable Management of Wetlands in Illubabor Zone, 13 December 1999, Addis Ababa, Ethiopia, 1999.

OECD: Guidelines for Aid Agencies for Improved Conservation and Sustainable Use of Tropical and Sub-Tropical Wetlands, Paris, France, OECD Guidelines on Aid and Environment, 9, 67 pp., 1996.

Onema, J. K. and Taigbenu, A.: NDVI-rainfall relationship in the Semliki watershed of the equatorial Nile, Phys. Chem. Earth, 34, 711-721, 2009.

Ozesmi, S. L. and Bauer, M. E.: Satellite remote sensing of wetlands, Wetl. Ecol. Manag., 10, 381-402, 2002.

Pantaleoni, E., Wynne, R. H., Galbraith, J. M., and Campbell, J. B.: Mapping wetlands using ASTER data: a comparison between classification trees and logistic regression, Int. J. Remote Sens., 30, 3423-3440, 2009.

Paolini, L., Grings, F., Sobrino, J. A., Jiménez Muñoz, J. C., and Karsebaum, H.: Radiometric correction effects in Landsat multidate/multi-sensor change detection studies, Int. J. Remote Sens., 27, 685-704, 2006.

Rahman, H. and Dedieu, G.: SMAC: a simplified method for the atmospheric correction of satellite measurements in the solar spectrum, Int. J. Remote Sens., 15, 123-143, 1994.

Ramsar Convention Secretariat: The Ramsar Convention Manual: a guide to the Convention on Wetlands (Ramsar, Iran, 1971), 4th edn., Ramsar Convention Secretariat, Gland, Switzerland, 2006.
Reimold, R. J.: Wetlands functions and values, in: Applied Wetlands Science and Technology, edited by: Kent, D. M., Lewis Publishers, Boca Raton, LA, USA, 55-78, 1994.

Riaño, D., Chuvieco, E., Salas, J., and Aguado, I.: Assessment of Different Topographic Corrections in Landsat-TM Data for Mapping Vegetation Types, IEEE T. Geosci. Remote, 41, 1056-1061, 2003.

Richter, R.: A spatially adaptive fast atmospheric correction algorithm, Int. J. Remote Sens., 17, 1201-1214, 1996.

Schroeder, T. A., Cohen, W. B., Song, C., Canty, M. J., and Yang, Z.: Radiometric correction of multi-temporal Landsat data for characterization of early successional forest patterns in western Oregon, Remote Sens. Environ., 103, 16-26, 2006.

Singh, A.: Digital change detection techniques using remotely sensed data, Int. J. Remote Sens., 10, 989-1003, 1989.

Smith, L., Lin, T., and Ranson, K.: The Lambertian assumption and Landsat data, Photogramm. Eng. Rem. S., 46, 1183-1189, 1980.

Song, C., Woodcock, C. E., Seto, K. C., Lenney, M. P., and Macomber, S. A.: Classification and change detection using Landsat TM data: When and how to correct atmospheric effects?, Remote Sens. Environ., 75, 230-244, 2001.

Tefera, M., Cherinet, T., and Haro, W.: Explanation of the Geological Map of Ethiopia, 2nd Edn., Bulletin No. 3, EIGS, Addis Ababa, Ethiopia, 79 pp., 1999.

Teillet, P. M., Guindon, B., and Goodenough, D. G.: On the slopeaspect correction of multispectral scanner data, Can. J. Remote Sens., 8, 84-106, 1982.

Teillet, P. M., Barker, J., Markham, B. L., Irish, R. R., Fedosejevs, G., and Storey, J. C.: Radiometric cross-calibration of the Landsat-7 ETM+ and Landsat-5 TM sensors based on tandem data sets, Remote Sens. Environ., 78, 39-54, 2001.

Thenkabail, P., Schull, M., and Turral, H.: Ganges and Indus river basin land use/land cover (LULC) and irrigated area mapping using continuous streams of MODIS data, Remote Sens. Environ., 95, 317-341, 2005.

Tiner, R. W.: Geographically isolated wetlands of the United States, Wetlands, 23, 494-516, 2003.

Töyrä, J. and Pietroniro, A.: Towards operational monitoring of a northern wetland using geomatics based techniques, Remote Sens. Environ., 97, 174-191, 2005.

UNESCO: National Water Development Report for Ethiopia, UNWATER/WWAP/2006/7, World Water Assessment Program, Report, MOWR, Addis Ababa, Ethiopia, 273 pp., 2004.

Van Dam, A. A., Dardona, A., Kelderman, P., and Kansiime, F.: A simulation model for nitrogen retention in a papyrus wetland near Lake Victoria, Uganda (East Africa), Wetl. Ecol. Manag.,15, 469-480, 2007.

Vermote, E. F., Tanré, D., Deuzé, J. L., Herman, M., and Morcrette, J. J.: Second simulation of the satellite signal in the solar spectrum, 6S: an overview, IEEE T. Geosci. Remote, 35, 675-686, 1997.

Vicente-Serrano, S. M., Perez-Cabello, F., and Lasanta, T.: Assessment of radiometric correction techniques in analyzing vegetation variability and change using time series of Landsat images, Remote Sens. Environ., 112, 3916-3934, 2008.

Vogelmann, J. E., Helder, D., Morfitt, R., Choate, M. J., Merchant, J. W., and Bulley, H.: Effects of Landsat 5 Thematic Mapper and Landsat 7 enhanced Thematic Mapper Plus radiometric and geometric calibrations and corrections on landscape 
characterization, Remote Sens. Environ., 78, 55-70, 2001.

Wagenseil, H. and Samimi, C.: Assessing spatio-temporal variations in plant phenology using Fourier analysis on NDVI time series: results from a dry savannah environment in Namibia, Int. J. Remote Sens., 27, 3455-3471, 2006.

Wei, W., Zhang, X., Chen, X., Tang, J., and Jiang, M.: Wetland Mapping Using Subpixel Analysis and Decision Tree Classification in the Yellow River Delta Area, The International Archives of the Photogrammetry, Remote Sensing and Spatial Information Sciences, Vol. XXXVII, Part B7, Beijing, 2008.

Wood, A. P.: Wetland drainage and management in south-west Ethiopia: Some environmental experiences of an NGO, in: The Sahel Workshop 1996, edited by: Reenburg, A., Marcusen, H. S., and Nielsen, I., Institute of Geography, University of Copenhagen, Copenhagen, 1996.

Wood, A. P.: Policy implications for wetland management, in: Proceedings of the National Workshop on Sustainable Wetland Management, 13 December 1999, Addis Ababa, Ethiopia, 117-127, 2000 .
Wood, A. P.: Wetlands, gender and poverty, in: Proceedings of a seminar on the resources and status of in Ethiopia's wetlands, edited by: Yilma, D. A. and Geheb, K., Wetlands of Ethiopia, Gland, IUCN, 58-66, 2001.

World Bank: Project appraisal document for the Rwanda Rural Sector Support Programme, Report No: 21048-RW, The World Bank, Washington DC, 2001.

Yohannes, F.: Soil Erosion and Sedimentation: The Case of Lake Alemaya, in: Proceedings of the Second Awareness Creation Workshop on Wetlands in the Amhara Region, Bahirdar, Ethiopia, September, 2005.

Yuan, D., Elvidge, C. D., and Lunetta, R. S.: Survey of multispectral methods for land cover change analysis, in: Remote Sensing Change Detection: Environmental Monitoring Methods and Applications, edited by: Lunetta, R. S. and Elvidge, C. D., Chelsea, MI: Ann Arbor Press, 21-39, 1998.

Zeleke, G.: Landscape Dynamics and Soil Erosion Process Modeling in the North-Western Ethiopian Highlands, African Studies Series, A16, Geographica Bernensia: Berne, 2000. 